\title{
REGISTERED OUTBREAKS OF ACUTE VIRAL HEPATITIS A IN STARA ZAGORA REGION, FOR THE PERIOD SEPTEMBER 2019 - MARCH 2020, IN THE MUNICIPALITIES BR. DASKALOVI, HRISHTENI, GALABOVO IN BULGARIA
}

\author{
I. Simeonova ${ }^{1}$, T. Perchemlieva ${ }^{2}$, St. Petrova $^{2}$, G.Trifonov $^{2}$, G. $_{\text {Iliev }}{ }^{3}$, I. Mladenova $^{1 *}$ \\ ${ }^{1}$ Department of Hygiene, Epidemiology and Infectious Diseases, Faculty of Medicine, \\ Trakia University, Stara Zagora, Bulgaria \\ ${ }^{2}$ Regional Health Inspectorate, Stara Zagora, Bulgaria \\ ${ }^{3}$ Non-Government Organization - World Without Borders, Office Stara Zagora, Bulgaria
}

\begin{abstract}
Viral hepatitis type A is an acute infectious disease, occupying $75 \%$ of all viral hepatitis.

Purpose of the study was to investigate three outbreaks, of viral hepatitis A in the municipalities of Stara Zagora region, from 09.2019-03.2020 in schools and kindergartens.

Methods: We investigated all cases from viral hepatitis A, for the municipalities of Bratya Daskalovi26, Hrishteni-19, Galabovo-21. A retrospective analysis and descriptive epidemiological methods have been used.

Results: The gender distribution shows that men were affected in $56 \%$ and women in $44 \%$. The children in the age group of 5-9 years - 49\%, as well as of $1-4$ years $-19.7 \%$ are most ill. The peak in the development of the outbreaks is in December 2019 (18\%) and January 2020 (48\%), which lasts until March with the so-called "Epidemic tail". Contact persons were not covered by the hepatitis A vaccine. The faecal-oral mode of transmission of infection has been proven. Specialized companies were engaged for the activities of current and final disinfection. Health educational activities aimed at improving hygiene habits have been carried out.

Conclusion: To prevent the outbreaks the cases have to be timely reported; Early examination of contact persons; Applications of a vaccine on the contact persons.
\end{abstract}

Key words: Acute viral hepatitis A, outbreaks, epidemic, anti-epidemic measures

\section{INTRODUCTION}

Acute viral hepatitis type $\mathrm{A}$ is an acute infectious disease of the liver, occupying $75 \%$ of the total structure of viral hepatitis, with a variety of clinical manifestations, from complete asymptomatic and subclinical manifestations to the development of fulminant hepatitis. (1)

The Republic of Bulgaria is in the middle endemic zone, with regard to acute viral

\footnotetext{
*Correspondence to: Irena Mladenova, Department of Hygiene, Epidemiology and Infectious Diseases, Faculty of Medicine, Trakia University, 6000 Stara Zagora, Bulgaria. E-mail: imladenova@yahoo.com; tel: 0897324472
}

hepatitis A, as a registered incidence. (In 2017 - $35.34 \% 000$ (2510 cases.); in $2018-19.11 \%$ 000 (1347 cases). For the Stara Zagora region, in 2019 , the incidence is $18.33 \% 000 ; 36.98 \%$ 000 - for 2018. The relative share of hepatitis A, compared to all viral hepatitis, is $61.70 \%$, in the Stara Zagora region, for 2019. $(1,2)$

Historically - the First Hepatitis Pandemic until 1922, related to the First World War. Infectious hepatitis has been widespread in both the warring armies and the civilian population (3);

The Second Hepatitis pandemic - has developed during World War II, covering the population of Europe, West Asia, North Africa, and the Pacific and Indian Ocean basins. The disease has acquired a ubiquitous character; 
The Third Hepatitis pandemic - After 1960. It also contains acute viral hepatitis type A, type B, type C, VHD (3).

There are three zones of endemicity:

1. Highly endemic area, with an incidence of 500-700\% 000;

2. Medium endemic area, with an incidence of 20-30\% 000, where the Republic of Bulgaria is;

3. Low endemic area, with an incidence below $10 \% 000$ (1).

For 2017 - in Bulgaria the incidence is 35.34\% 000 (2510 following); $2018-19.11 \% 000$ (1347 cases) (2).

\section{PURPOSE AND TASKS}

Study of three epidemic outbreaks in parallel of acute viral hepatitis type $A$ in the municipalities of Bratya Daskalovi, the village of Hrishteni and the town of Galabovo from 09.2019 to 03.2020 , in schools and kindergartens.
SIMEONOVA I., et al. To analyze the risk factors, as well as the antiepidemic and prophylactic measures taken.

\section{MATERIALS AND METHODS}

We conducted epidemiological studies of all cases from acute viral hepatitis A, for the municipalities of Bratya Daskalovi-26, Hrishteni-19, Galabovo-21. The patients were hospitalized in the Infectious Diseases Clinic, St. Zagora. The contact persons were followed up clinically and laboratory, for the maximum incubation period. A retrospective analysis was made, on the maps for epidemiological research, of the time of the outbreaks. Descriptive epidemiological methods have been used.

\section{RESULTS}

Registered outbreaks of acute viral hepatitis $A$ in Stara Zagora region, for the period September 2019 - March 2020, in the municipalities Br. Daskalovi, Hrishteni, Galabovo in Bulgaria.

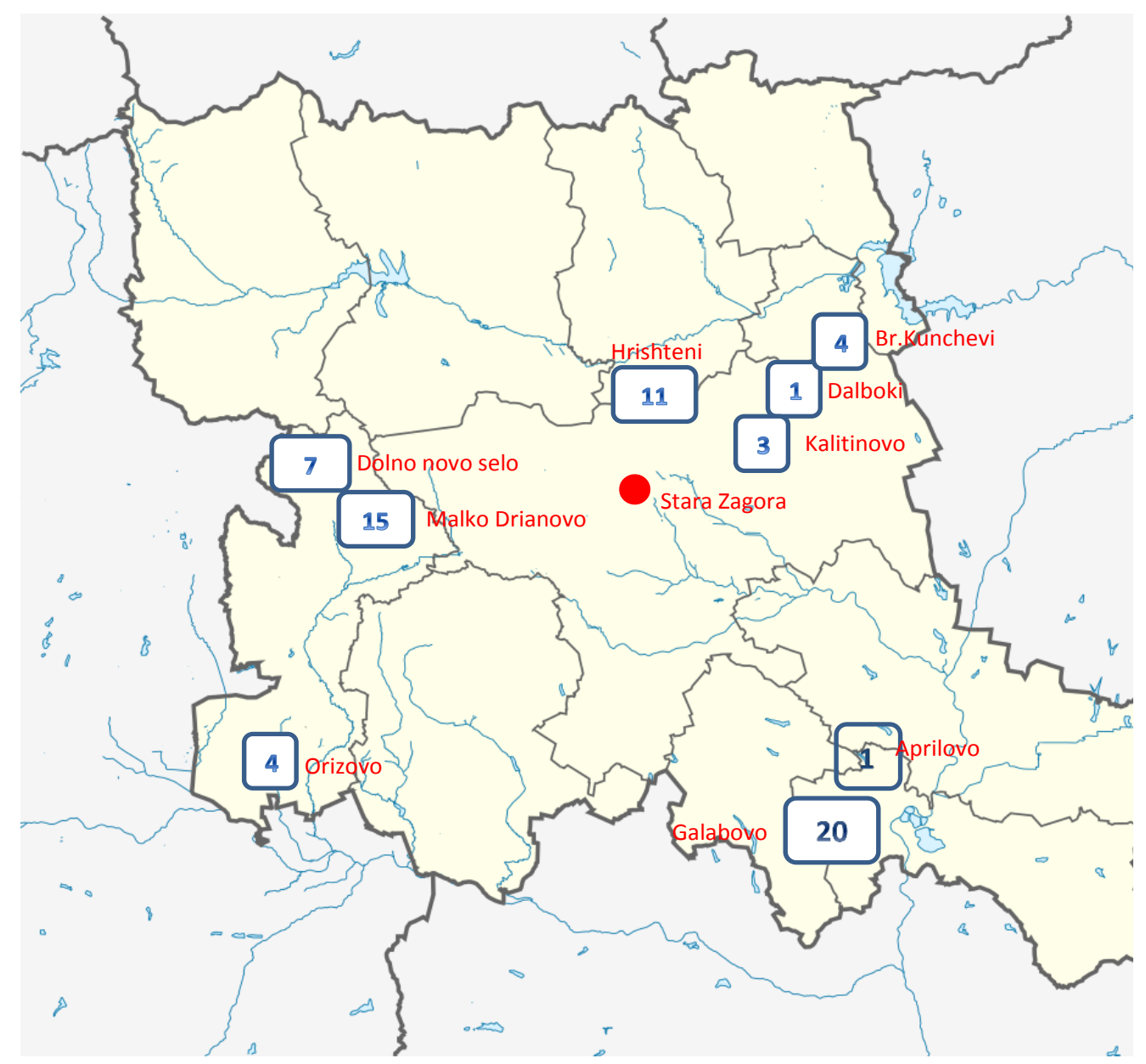

09.03 .2020

Figure 1. Distribution of cases in Stara Zagora region, in Bulgaria. 


\section{FIRST OUTBREAK}

For the period from September 2019 February 2020, a total of 26 cases of acute viral hepatitis $A$ have been registered in the municipality of Bratya Daskalovi.

All cases have been investigated.

The first case is a 5-year-old child from the village of Malko Dryanovo, attending the kindergarten in the village.

According to anamnestic data, the grandfather of this child "some time ago suffered from liver disease" and resided in the village of Gradets, Sliven region, on the occasion of a fair. He probably has made a contact there. After that two brothers in the family have fallen ill within a month.

In the epidemic situation, the territorial distribution is as follows: the village of Malko Dryanovo - $15(58 \%)$ of the patients in the municipality, in the village of Dolno Novo Selo - 7 patients $(27 \%)$ and in the village of Orizovo - 4 (15\%).

Family outbreaks: from the village of Malko Dryanovo - 4 households, with two or three patients, from the village of Dolno Novo Selo 3 households, with two patients each and from the village of Orizovo - from one household 4 patients.

The distribution by the attendance of children's and school groups is as follows: kindergarten in the village of Naidenovo - 6 children ill;

The school in the village of Bratya Daskalovi 9 of different classes; kindergarten in the village of Orizovo - 2 children and kindergarten in the village of Bratya Daskalovi - 1 child.

8 adult members of the family groups also have fallen ill: one of them works as a shepherd in the village, 1 - a cleaner in two households, 1 - a general worker.

\section{SECOND OUTBREAK}

For the period from 17.12.2019 to 06.02.2020, in the town of Galabovo, 21 sick children of Roma origin were reported, from acute viral hepatitis type A (in Galabovo -20 and in the village of Aprilovo-1).

Attendance distribution: 17 (80.9\%) are students at the school in Galabovo. The study found that hygiene habits were lowered before breakfast. The educators have had to actively wash and disinfect the children's hands. In four
SIMEONOVA I., et al.

of the patients no commitment to an organized team was established. The first case was in December 2019, followed by 16 cases in January and 4- in February.

There were 7 actively found- approximately $33 \%$ of all cases.

\section{THIRD OUTBREAK}

Since the end of December 2019, on the territory of Stara Zagora region, an outbreak of acute viral hepatitis A has been registered in the village of Hrishteni, as the first 3 cases are in children in the kindergarten of the village, 1 case in the school in Hrishteni, 1 case - in the school in the village of Dalboki and 1 sick in the home (adult from the village of Kalitinovo).

Subsequently, 11 cases have occurred, after 60 days, and it should be noted that the cases in the village of Hrishteni (outside the kindergarten) continue protracted in March 2020.

The second wave of sick children in the kindergarten starts - 2 children- in March 6, 2020.

With specific prescriptions to the municipality, in the village of Hrishteni, and to the general practitioners, specific anti-epidemic measures and medical monitoring of the contact children and staff have been taken.

Extensive health and educational activities were carried out, with the assistance of the municipality, the general practitioners in the village of Hrishteni, the health workers and mediators from "World without Borders".

In the organized teams the distribution is as follows: kindergarten in the village of Hrishteni - 5 cases, for primary school in the village of Hrishteni - 5 cases, and one case in the other schools: Dalboki Primary School, Preslaven Primary School, Br. Kunchevi Primary School, and Hristo Botev School, Stara Zagora. Four children became infected in the family outbreaks and one adult at home.

The children travel by organized transport, from three buses, on which current and final disinfection has been done, according to the prescription of RHI Stara Zagora, from a specialized DDD company, in the kindergarten in the village of Hrishteni and the primary school in the village of Hrishteni. 
The gender distribution of all cases in the 3 outbreaks shows that men are affected in 56\% and women in $44 \%$ (Figure 2.). Children in the age group of 5-9 years - 49\%, as well as of 1 4 years $-19.7 \%$ are most ill (Figure 3.). The peak in the development of the epidemic process is in December $2019(18 \%)$ and January 2020 (48\%), which lasts until March, with the so-called "Epidemic tail" (Figure 4.). Contact persons were not covered by the
SIMEONOVA I., et al. hepatitis A vaccine. The faecal-oral route of transmission of the infection has been proven. Prescriptions have been issued by RHI; specialized DDD companies have been involved in the activities of current and final disinfection of the sites and school buses. Health and educational activities and activities aimed at improving hygiene habits have been carried out.

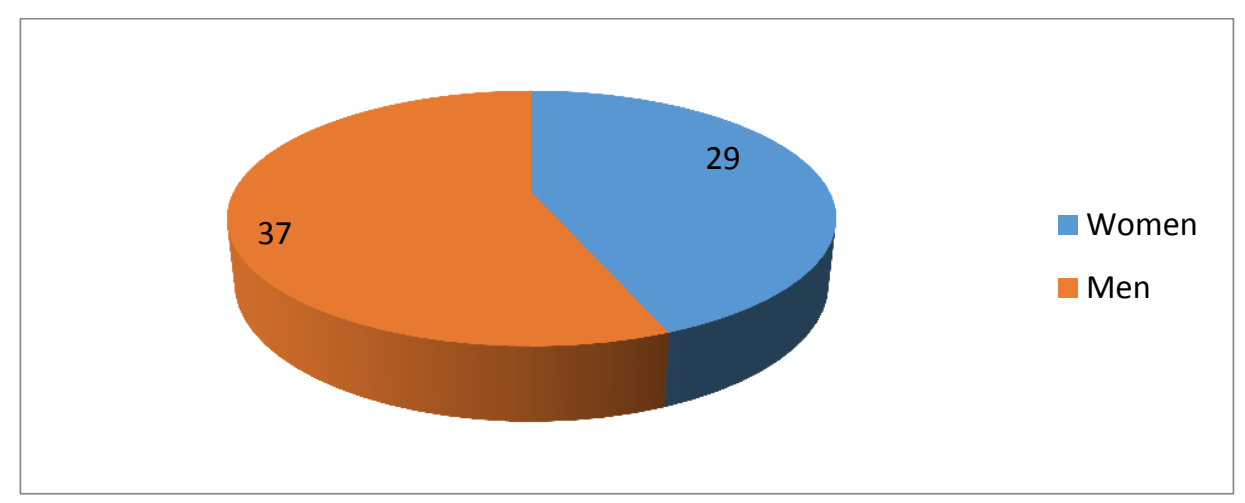

Figure 2. Gender distributions of patients.

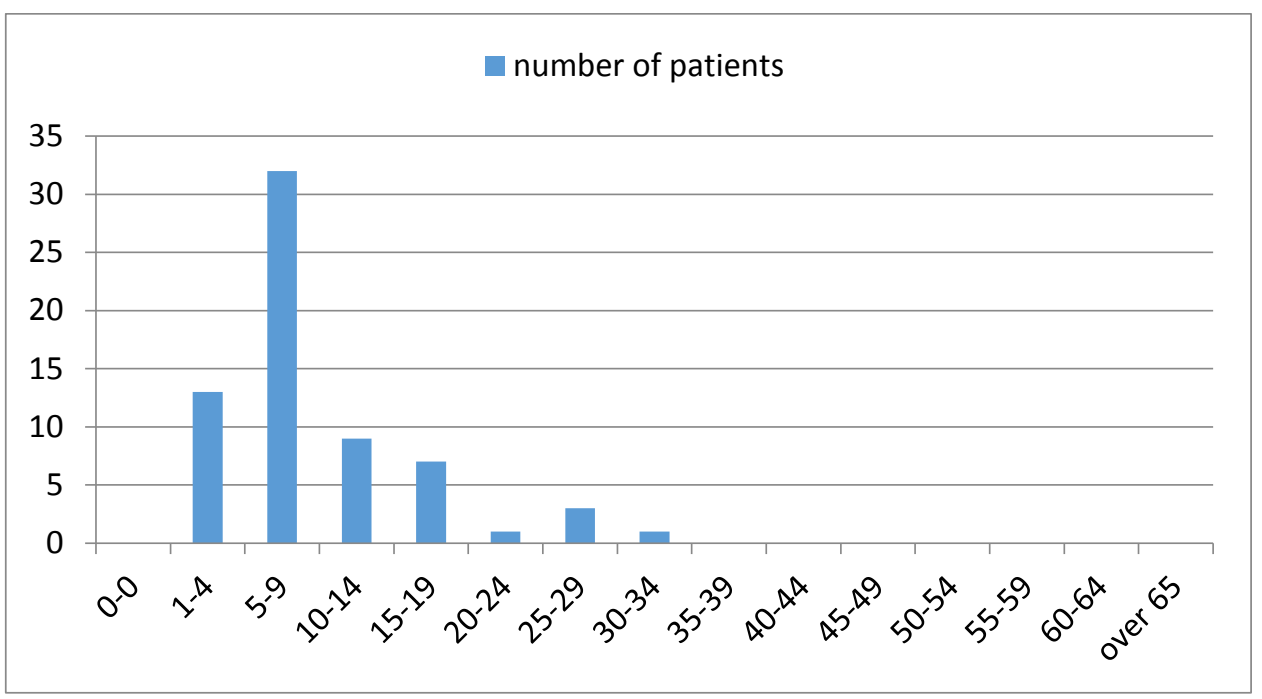

Figure 3. Age distribution of patients.

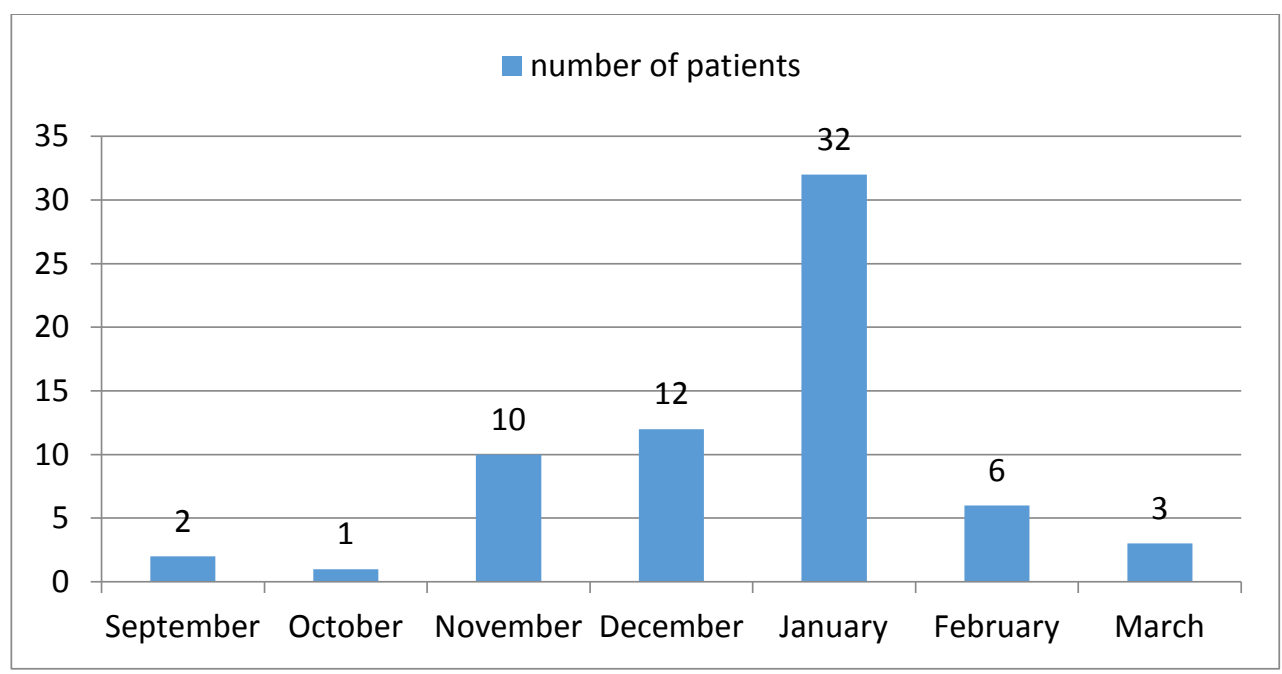

Figure 4. Distribution of patients by month. 
The high incidence is with usual autumnwinter seasonality. All cases were benign; there are no fulminant forms of the disease. Exit from the disease - recovered, and one patient had to be re-hospitalized in the Infectious Diseases Clinic. Many of the cases have been actively detected as a result of medical observation and epidemiological investigation.

\section{Prophylactic and anti-epidemic measures in epidemic outbreaks:}

1. Timely reporting of cases (4), timely hospitalization and treatment.

2. Observance of a strict anti-epidemic regime in the organized teams, and weekly examination, with test strips, of urine, for bilirubin and urobilinogen. Registration of suspicious results, and referral for consultation with an infectious disease specialist. Examination of serum aminotransferases of staff and children by relevant general practitioners and presentation of the results to the school health authorities.

3. Quarantine in the kindergarten and suspensions of the admission of new children, for the period of observation, in the only group of the kindergarten.

4. Carrying out an extended study of serum aminotransferases of the contact persons.

5. Reporting of the outbreaks in the Ministry of Health, NCIPD, Sofia.

6. A recommendation of the Ministry of Health to carry out immunizations with anti-hepatitis vaccine type A was discussed, but due to lack of funds, the latter was not given.

7. Carrying out disinfection activities in the school, kindergartens and the school bus, periodically by a specialized DDD company, on the prescription of RHI Stara Zagora.

8. Prescription of the municipalities to carry out strict control over the regular garbage disposal of household waste.

9. Samples from the external environment were taken from kindergartens and schools, a total of 19 , and samples from biocides - 8 , as
SIMEONOVA I., et al. well as four for microbiological analysis, from the central water supply, from which no deviation was found in the results.

10. Health education activities and activities aimed at improving hygiene habits, which in some households are at a very low level.

\section{CONCLUSIONS}

In the course of our research and monitoring of outbreaks, it is established that children and school children are affected in terms of the accumulation of the "non-immune" population and the organization of the educational process. Poor hygiene habits should also be taken into account, despite the central water supply provided and the lack of a "water" regime.

Recommendations: To prevent the outbreaks the cases have to be timely reported; Early examination of contact persons; Applications of vaccine on the contact persons, Active educational activities with the purpose of promoting the health culture and education of correct hygiene habits.

\section{REFERENCES}

1. Ribarova, N. et. all. Epidemiology of infectious diseases, Simelpres, Sofia, Bulgaria, 2011.

2. Kurchatova, A., Vladimirova, T., Minkova, A.,Kamenov G, Stoicova S, Parmakova, K. Acute Infectious Diseases in Bulgaria in 2018;2019, (Basic Epidemiological Indicators)

3. https://www.ncipd.org/images/UserFiles/Fil e/Analizi/Analysis_CD_Bulgaria_Text_Tab les_2018.pdf3. 3. Iliev B. and Mitov G. Epidemiology of infectious and noninfectious diseases, Medicina i fiskultura, Bulgaria, 1994.

4. Ordinance No 21 of 18 July 2005 on the Procedure for Registration and Reporting of Contagious https://lex.bg/bg/laws/ldoc/2135508238 